\title{
The Role of the Constitution in Effective Disaster Management of Bangladesh
}

\author{
Fayjus Salehin ${ }^{1}$, Md. Nuralam Hossain ${ }^{2 *}$, Abdur Rakib Nayeem ${ }^{1,3}$, Md. Rakibul Hassan ${ }^{4}$ \\ ${ }^{1}$ Times University Bangladesh, Faridpur 7800, Bangladesh \\ ${ }^{2}$ School of Environment and Ecology, Chongqing University, Chongqing 400045, China \\ ${ }^{3}$ School of Economics and Business Administration, Chongqing University, Chongqing 400045, China \\ ${ }^{4}$ Department of Environmental Science and Engineering, Jatiya Kabi Kazi Nazrul Islam University, \\ Trishal, Mymensingh-2224 Bangladesh \\ *Corresponding author (E-mail: nuralam_esrm@yahoo.com) | ORCID: 0000-0003-0029-9367
}

How to cite this paper: Salehin, F., Hossain, M.N., Nayeem, A.R. and Hassan, M.R. (2020). The Role of the Constitution in Effective Disaster Management of Bangladesh. Grassroots Journal of Natural Resources, 3(2): 57-69. Doi: https://doi.org/10.33002/nr2581.6853.03025

Received: 28 May 2020

Reviewed: 31 May 2020

Provisionally Accepted: 02 June 2020

Revised: 10 June 2020

Finally Accepted: 15 June 2020

Published: 22 June 2020

Copyright (C) 2020 by author(s)

This work is licensed under the Creative Commons Attribution International License (CC BY 4.0). http://creativecommons.org/licenses/by/4.0/
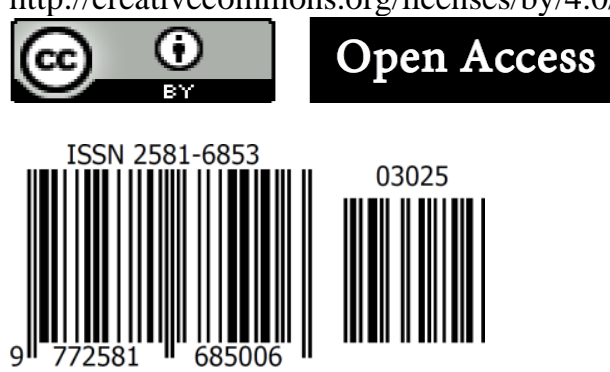

\begin{abstract}
Bangladesh is prone to recurring natural hazards due to its geographical position and topography. The country has suffered casualties and damage to homes, agriculture, and the economy as a result of tropical cyclones. Effective disaster management approaches are required to reduce the risk of disaster and loss. The Constitution of Bangladesh plays an active role in implementing these approaches at the national and sub-national level. This article analyzes parts of the Constitution addressing disaster management by ensuring disaster governance and adaptive governance. To examine the theoretical aspects of disaster management from a global and Bangladesh perspective, the current institutional role for disaster management, the difference in service delivery for specific organizations, and human rights and humanitarian aspects, a study was conducted based on secondary data and information. Bangladesh's supreme law supports all phases of the disaster management cycle. Consequently, it is said that the Constitution would be an essential document for effective disaster management at all levels.
\end{abstract}

\section{Keywords}

Disaster governance, Adaptive governance, Disaster management, Constitution, Bangladesh 
Doi: https://doi.org/10.33002/nr2581.6853.03025

\section{Introduction}

According to the United Nations (UN), "Disaster is a serious disruption to the functioning of a society or community due to extensive material, human, economic or environmental influences, which is beyond the capabilities of the affected community or society to cope using its resources" (UNISDR, 2015; Hossain, Rahman and Islam, 2016). The Hyogo Framework for Action 20052015 (HFA) played a significant role in disaster risk reduction and adopted a guideline for mitigating disaster vulnerability by UN member countries in 2005 . The HFA provides five priority areas for action, guidelines, and practical tools for achieving disaster resilience for vulnerable communities in the context of sustainable development (UNISDR, 2005; Jones et al., 2014; Hasan, Nasreen and Chowdhury, 2019). SAARC ${ }^{1}$ Comprehensive Disaster Management Framework also included the spirit of HFA action framework. All policies reflect the government's strong commitment to disaster risk reduction concepts (Rezoane, 2016). The Millennium Declaration of September 2000 stipulated that Bangladesh's disaster management policy was prepared to reduce disaster risk by ensuring public participation. Mitigating natural disaster risk is the key to this policy, and it emphasized that the poor suffered to natural disasters. Similarly, the Sustainable Development Goals (SDGs) are policy priorities aimed at improving the resilience and reducing the vulnerability of the poor (Shaw, Mallick and Islam, 2013). The main thrust is how to develop the necessary risk reduction processes, focusing on the poor and vulnerable people.

Bangladesh is considered one of the most disaster-prone countries in the world (BDRCS, 2008; Hossain, Rahman and Islam, 2016). The country's geographical location and climate make it the most vulnerable to natural and manmade disasters (MoEF, 2013; Ahamed, Rahman and Faisal, 2012). Frequent natural calamities such as floods, tropical cyclones, storm surges, flash floods, droughts, riverbank erosion, and landslide frequently hit the country. As a result, it negatively affected the entire ecosystem, including humans, their shelters, or the resources necessary for their livelihood (Hasan, Nasreen and Chowdhury, 2019; Hossain et al., 2015). The country is located in the Ganga-Brahmaputra river delta, one of the most fertile plains in the world. Together, they are more vulnerable to river erosion, floods and cyclones (Hassan, 2015; Hossain, Rahman and Islam, 2016). The tropical cyclones cause most devastating natural disasters, causing casualties and damage to housing, agriculture and the economy (Sarker et al., 2019a). The sustainable development needs to mitigate the adverse effects of these natural hazards that affect socioeconomic conditions. Realizing this, the Government of Bangladesh has launched a series of disaster reduction plans and programs through Comprehensive Disaster Management (Hossain, 2011; Izumi and Shaw, 2015). Currently, the main documents dealing with disasters in Bangladesh are the Disaster Management Act 2012, the National Disaster Management Policy 2015, the Standing Order on Disasters 1997 (revised on 2010), the Division of Disaster Management and Disasters (DM \& RD) and the National Plan for Disaster Management 2010-2015. Bangladesh also has a disaster management mechanism at national and sub-national level. Bangladesh National Plan for Disaster Management is a key strategic document. It is a holistic plan that provides comprehensive guidance to relevant departments and disaster management committees for the implementation of specific plans at their functional level and their role for different levels of administrative structure (Hossain, 2011; Rezoane, 2016).

\footnotetext{
${ }^{1}$ South Asian Association for Regional Cooperation 
Every disaster, whether natural or manmade, deliberately affects human rights in society. The aim of coping with natural disasters should, therefore, be to protect the human rights of citizens. Human rights are the legal basis for all humanitarian activities related to natural and manmade disasters (Jonsson, 2003; Pietropaolo, 2016). If humanitarian aid is not linked to human rights, it can be too narrow. It cannot integrate all the basic needs of victims into a holistic planning process (Kent, 2002; Suwanvanichkij et al., 2010). Furthermore, neglecting the human rights of the people affected by natural and manmade disasters is gross violation of right to life (Lewis and Maguire, 2016). After independence in 1971, Bangladesh enacted a well-written Constitution in 1972. The Constitution's task is to guarantee the basic human rights of the people. But the people of Bangladesh do not know much about their rights. The Government of Bangladesh passed the Disaster Management Act in 2012, which sets out the responsibilities of various organizations (Azad et al., 2020). The article 19 of the Constitution embodies the "Equality of Opportunity" but supplementary article could be added with the article 19 in the Constitution mentioning that a vulnerable group will have a high priority compared to less vulnerable people. If the Constitution helps in dealing with natural calamities, then it becomes easier to deal with different natural disasters, because all the concerned authorities, including the government, feel a sort of compulsion under the supreme law of the nation (Ahmed, 1978).

Therefore, it is essential to critically assess that various articles of the Bangladesh Constitution support an effective disaster management policy. To do this, authors first analyzed the articles of the Constitution relating to disaster management policies. The issues of human rights and fundamental rights enshrined in the Constitution were analyzed. Finally, the obligations of the Bangladesh government to handle different disasters effectively are identified. It is recommended that specific articles on the rights of people affected by natural disasters should be included in the Constitution through appropriate amendments.

\section{Methodology}

The articles of the Constitution addressing disaster management, disaster governance and adaptive governance were analyzed. A systematic literature review has been conducted for understanding the Constitution in context of disaster management from the perspective of Bangladesh, different institutions meant for disaster management, gaps between services being provided and the roles of the designated organizations, human rights and humanitarian factors (Pal and Shaw, 2018). Literature was sourced from databases like Scopus and Web of Science using keywords such as "disaster management, role of Constitution, disaster governance and adaptive governance". Furthermore, secondary data was obtained from Bangladesh Disaster Management Cell, Disaster Management Bureau, Ministry of Food and Disaster Management, books, magazines, newspaper, and published articles.

\section{Results and Discussion}

\section{Disaster Management Cycle}

The disaster management cycle is a continuous process of reducing risks and exposure to hazards (i.e., mitigation), of planning and preparing for forthcoming hazards, and of responding to prevent natural disasters (i.e., preparedness). It includes phases of reducing impacts of a disaster through response efforts to search and rescue (i.e., response) and restoration through clean up and 
reconstruction (i.e., recovery) (Poser and Dransch, 2010; Harrison and Johnson, 2016). A complete disaster management cycle includes the development of public policies and plans that either address the causes of disasters or mitigate the effects on people, property and infrastructure (Harrison and Johnson, 2016).

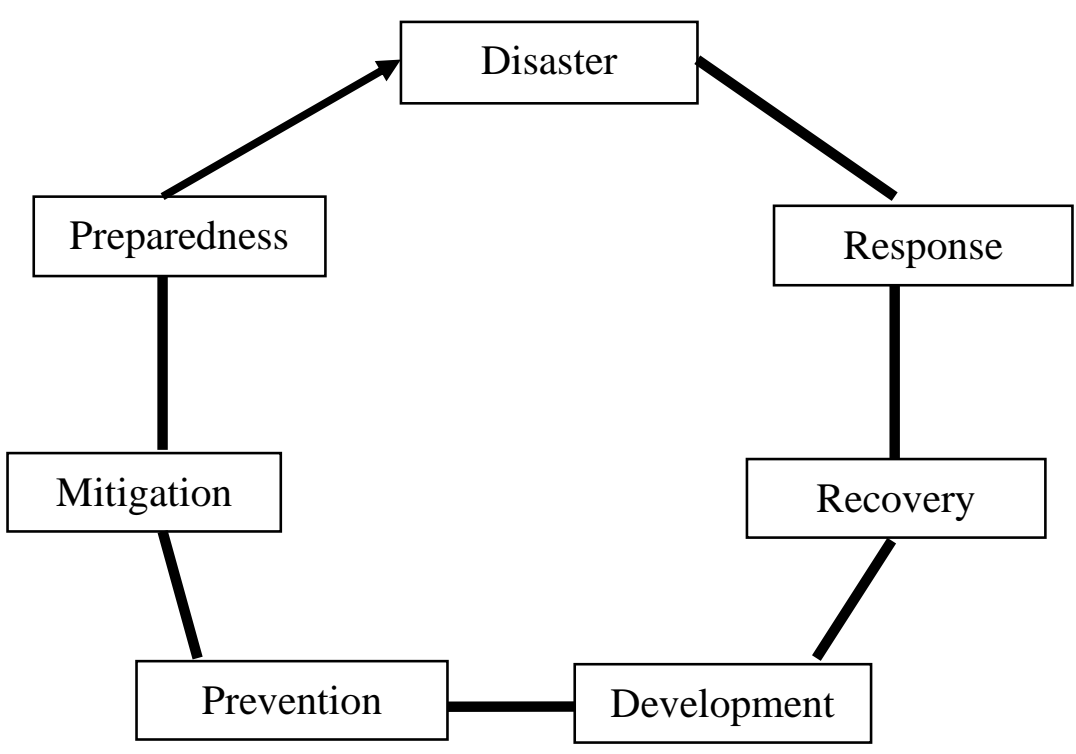

Figure 1: Disaster management cycle (Warfield, 2005; Harrison and Johnson, 2016)

\section{Institutional Framework of Disaster Management in Bangladesh}

The disaster management concept of the Government of Bangladesh is to reduce the risk to the people, especially the poor and the backward. It intends to create an effective Emergency Response System under which large-scale disasters can be handled along with the humanitarian issues while managing the effects of natural, environmental and manmade hazards (Khan and Rahman, 2007; Sarker et al., 2019b). Bangladesh began disaster preparedness after the 1991 cyclone. Currently, Bangladesh has the National Disaster Management Act 2012 (MoDMR, 2012), the National Disaster Management Policy 2015 (MoDMR, 2015), Standing Order on Disasters 1997 (revised in 2010) of the Department of Disaster Relief and Management (DM \& RD), and the National Disaster Management Plan 2010-2015 (MoDMR, 2010) as essential documents to guide disaster management activities in Bangladesh (Khan and Rahman, 2007; Izumi and Shaw, 2015). The country also has disaster management mechanisms at the national and sub-national levels. Bangladesh National Disaster Management Plan is a strategic document. It provides a comprehensive guide for relevant sectors and disaster management committees at all levels to prepare and implement specific plans created under various thematic levels of administrative structures (Hossain, 2011; Hassan, 2015; Rezoane, 2016).

\section{Relationship between Constitution and Disaster Management Policy}

If the Constitution supports disaster prevention, it is easier to respond to any sorts of disaster because all the concerned authorities, including government, work under compulsion from the supreme law of the nation. The government cannot pass any law that is inconsistent with the 
Constitution. People also need robust and resilient environment to combat a variety of natural or manmade disasters. Bangladesh Constitution directly supports the disaster management and human rights of affected people. The Bangladesh Constitution dictates governments and other organizations to manage disasters, all the institutions, including the Government of Bangladesh, have to follow the Constitution (Kamal, 1994; Chaudhury, 1995).

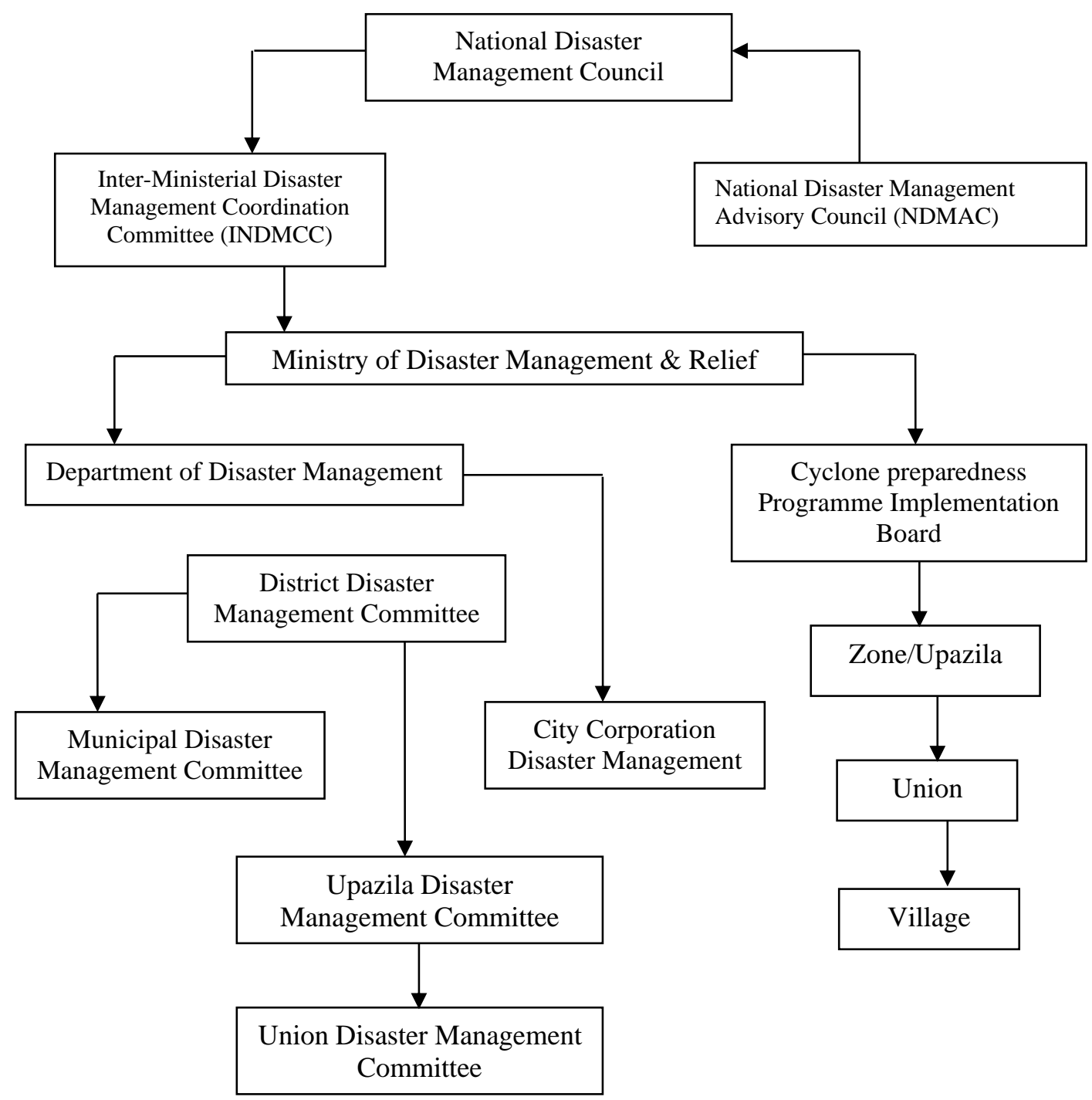

Figure 2: Institutional Framework of Disaster management in Bangladesh (Khan and Rahman, 2007).

Table 1 shows that Article 10 focuses on achieving a reasonable and equitable society. An egalitarian society manages disasters more effectively than a non-egalitarian society. For example, cyclone Nargis killed more than 300,000 people in Myanmar (Seekins, 2009), while cyclone Sidr killed 3,363 people in Bangladesh, although Sidr was more powerful than cyclone Nargis (MoDMR, 2010; South, 2008). Higher number of casualties was recorded in Myanmar due to poor government system and lack of proper disaster management policy. Similarly, an earthquake occurred in Haiti in 2010 (magnitude of Mw 7.0) caused 300,000 deaths (Gorum et al., 2013). A few years later, a similar 7.1 magnitude earthquake in New Zealand did not kill that many people because of its sustainable social and political structure (Potter et al., 2015). It is, hence, laudable 
that a democratic society plays a vital role in disaster management (Rahman, Khan and Shaw, 2015). The elected governments always remain under intense pressure from the people and the media; as a result, the governments actively work to satisfy the people's needs by taking appropriate measures to deal with the disaster. Democracy and human rights are determinants because countries with no democracy ignore human rights issues. Having no democracy, a government does not feel any pressure from the people to take appropriate measures to reduce or prevent disasters (Kent, 2002; Johnson, 2003). Article 11 of the Constitution explicitly states that a republic government should have a democracy and good governance that guarantees fundamental human rights and freedoms, which respect for human dignity and value (Rahman, 2006; Panday, 2016). The people are actively involved through their elected representatives in administration at all levels (Halim, 1997).

Table 1: Fundamental Principles of the State Policy in relation to Disaster Management

\begin{tabular}{lc}
\hline Article no. and theme & Constitution part \\
\hline Article 10: Socialism and freedom from exploitation & \\
Article 11: Democracy and human rights & \\
Article 12: Secularism and freedom of religion & \\
Article 14: Emancipation of peasants and workers & Part II \\
Article 15: Provision of necessities & \\
Article 16: Rural development and agricultural revolution & \\
Article 17: Free and compulsory education & \\
Article 18A: Protection and improvement of environment and biodiversity & \\
Article 19: Equality of opportunity &
\end{tabular}

Article 12 of the Constitution talks about secularism and religious freedom, as the people belonging to religious minorities are the most severe victims of any calamity. The government does not usually focus on religious minorities (Panday, 2016); yet, without secularism and freedom of religion, a well-designed and effective disaster management system is not possible (Bankoff, 2002). For example, the Rohingya religious minority community in Myanmar was stricken hardest during and after cyclone Nargis (South, 2008; Kingston, 2015). On the contrary, similar situations do not usually occur in Bangladesh because Article 12 of the Constitution ensures secularism and religious freedom. In fact, it is the right of minorities to receive advantage equivalent to that of majority people, which ultimately triggers successful disaster management (Ahmed, 1978). Article 28 also supports the provisions given in Article 12. It states that "the State must not discriminate against a citizen solely based on the religion, race, caste, gender or place of birth" (Alam, Shaifullah and Mahmud, 2013). Finally, Article 12 serves as protection for the religious minority in context of disaster management (Halim, 1997). It can, therefore, be said that the Bangladesh Constitution plays a vital role in protecting religious and other minorities in event of disasters.

Bangladesh's economy continues to depend on agriculture, which accounts for about $35 \%$ of gross domestic product (GDP) (Mistri, Rahman and Khatun, 2015; Hossain et al., 2019), and the farmers and workers are the main drivers of the Bangladesh economy. However, these two groups of people are most susceptible to different disasters. Without the contribution of farmers and workers, it is impossible to advance the country. In general, workers and day labourers lose their livelihoods during cyclones and floods. Article 14 of the Bangladesh Constitution gives priority to the rights of farmers and workers. Article 14 clarifies that the primary responsibilities of the State are to 
protect working people and farmers from all forms of exploitation. The main victims of disasters in Bangladesh are the landless workers, farmers and lower strata people of society. If people's basic needs can be met, their resilience can increase, and they can earn extra income from some manufacturing activities. Previously, countless people affected by disasters suffered from the unavailability of necessary goods and services. Now, fortunately, the Bangladesh Constitution guarantees all basic needs of the citizens. Article 15 of the Constitution protects livelihoods as well and guarantees the basic necessities of life, including food, clothing, shelter, education and medical care. The Constitution also guarantees the right to work, which ensures employment at a reasonable wage, quantity and quality of work. Disaster-affected people, especially small businesses and day labourers, lose their livelihoods (Nasreen, 2009).

Most of the people of Bangladesh live in rural areas. Understandably, the development of rural economy means the development of the whole country (Faisal and Parveen, 2004). On the other hand, rural areas are most vulnerable to disasters such as cyclones and floods due to poor infrastructure (Mishra, 2001; Siddiqui and Hossain, 2006). Cyclones and large floods killed millions of rural people between 1971 and 2014. But mortality rates have declined significantly in recent years because of a program of disaster preparedness by various government and nongovernmental organizations (Mishra, 2001; Siddiqui and Hossain, 2006). Rural and coastal residents are most vulnerable to cyclones and storm surges. Frequently, various disasters, especially cyclones, storm surges and floods, have destroyed a significant number of rural crops, which ultimately affected the rural economy. Article 16 of the Bangladesh Constitution progressively promotes the agricultural revolution, rural electrification, development of households and other industries, education, communication and improvement of public health in rural areas. Sustainable development in rural areas significantly reduces susceptibility to natural and manmade disasters in Bangladesh. As a result, the Bangladesh Constitution is strongly supported by addressing disasters through sustainable development in rural areas.

Education is the foundation of a nation. Generally, educated people are less vulnerable to different natural disasters because they are well aware of disaster and know how to adopt with disasters. Further, they follow various national and local level adaptation measures to cope with different disasters independently. It is often seen that fires occur in the city of Dhaka. The poor and illiterate people lose their lives and valuable resources. Due to their illiteracy, they are not aware of various hazards and disaster that they are exposed to and plenty of damages occur. Moreover, sometimes they do not care about government regulations. For this reason, about 3,500 people died during the Sidr cyclone because they did not follow the government's instructions. Article 17 of the Bangladesh Constitution emphasizes compulsory education. If people receive adequate training, they will learn more about the intensity of disaster and keep them aware and protected.

Protecting the environment and biodiversity can help prevent or mitigate natural disasters (Hossain, Rahman and Islam, 2016). For example, the Sundarbans protected Syamnagar and Koyra upazila during the cyclone Sidr. Usually, the green belt of the coastal zone is used as a protective shield during a cyclone. A treeless environment can cause excessive loss and desertification (Ghosh et al., 2020). Northwest region of Bangladesh is used to combat drought in summer and winter; as a result there is water scarcity in these areas. But, the forest will reduce global warming in those parts of the country. Article 18A of the Bangladesh Constitution prioritizes the protection and enhancement of habitat and biodiversity. 
The poorest of poor people are the most vulnerable to disasters (Kruhl, Adhikari and Dorka, 2018). But if the government guarantees equal opportunities for all, most people are bound to be safe. Yet, during every cyclone or flood, it turns out that the most miserable people receive less aid than the influential groups. Thus, the most vulnerable people are always deprived of all opportunities (Siddiqui and Hossain, 2006); however, Article 19 of the Constitution gives everyone the right to equal opportunities. If all citizens have equal opportunities, Bangladesh can become the most resilient nation in event of disasters. People living in coastal areas or on different islands like Sandeep, Kutubdia, St. Martin, Bhola, Hatia, etc. migrate to Dhaka or Chittagong cities. They do not get enough opportunities in their respective villages compared to the residents of big cities. Such a deprivation creates more vulnerability of poorest of poor people. Equal opportunities can help build a peaceful and sustainable society and a resilient nation.

Table 2: Fundamental rights in relation to the disaster management

\begin{tabular}{ll}
\hline Article no. and theme & Constitution Part \\
\hline Article 28: Discrimination on the grounds of religion, etc. & \\
Article 36: Freedom of movement & Part III \\
Article 39: Freedom of thought and conscience and speech & \\
\hline
\end{tabular}

As mentioned in Table 2, Article 36 of the Constitution of Bangladesh makes it clear that citizens have the right to move freely around Bangladesh, to live and reside anywhere and to travel and return to Bangladesh. However, riverbank erosion is a major disaster in Bangladesh. The erosion of the riverbank causes thousands of people to lose their homes and to move to new areas, forcing the affected people flee to urban cities every year (Siddiqui and Hossain, 2006). Such a movement is possible because Article 36 of the Bangladesh Constitution describes freedom of movement. Likewise, if the press is independent, starvation is not possible in any country, as the media reveals all starvation cases. The media plays an essential role in disseminating basic information, especially to vulnerable people in disaster management, and therefore helps the government find the right news (Berkholder-Allen, 1999; Momtaz, 2013). Press has gained freedom through Article 39 of the Constitution of Bangladesh. A seasonal famine called Monga in northern part of Bangladesh was eradicated due to mass media reports filed by print and electronic media of Bangladesh.

\section{Role of the Constitution in the Disaster Management Cycle}

The effective disaster management cycle consists of four main stages: prevention/remediation, preparedness, feedback and recovery (Harrison and Johnson, 2016). From previous discussions, it is clarified that Constitution of Bangladesh plays an essential role in the effective management of natural disasters. The articles of the Constitution of Bangladesh having positive impact on different stages of the disaster management cycle are mentioned in Table 3.

Table 3: Disaster management cycle and the Constitution

\begin{tabular}{llll}
\hline \multicolumn{2}{l}{ Disaster management stages } & & \\
\hline Prevention/Mitigation & Preparedness & Response & Recovery \\
\hline $\begin{array}{l}\text { Article 15: Provision of } \\
\text { necessities }\end{array}$ & $\begin{array}{l}\text { Article 10: Socialism } \\
\text { and freedom from } \\
\text { exploitation }\end{array}$ & $\begin{array}{l}\text { Article 21: Duties } \\
\text { of citizens and } \\
\text { public servants }\end{array}$ & $\begin{array}{l}\text { Article 21: Duties } \\
\text { of citizens and } \\
\text { public servants }\end{array}$ \\
\hline
\end{tabular}


Doi: https://doi.org/10.33002/nr2581.6853.03025

Article 16: Rural development and agricultural revolution

Article 17: Free and compulsory education

Article 18A: Protection and improvement of environment and biodiversity

Article 39: Freedom of thought and conscience and speech

Article 11: Democracy
and human rights

Article 14:

Emancipation of peasants and workers

Article 17: Free and compulsory education

Article 28:
Discrimination on
the grounds of
religion, etc.
Article 37 :
Freedom of
assembly

Article 28:

Discrimination on

the grounds of religion, etc.

Article 37:

Freedom of

assembly

Article 39:

Freedom of thought and conscience and speech
Article 19: Equality of opportunity

Article 23A: The culture of tribes, minor races, ethnic sects and communities

Article 27: Equality

before the law

Article 36: Freedom of movement

\section{Influence of Constitution in Disaster Management Cycle}

Figure 3 depicts the influence of the Constitution of Bangladesh on different stages of disaster management cycle. All stages relate to $88 \%$ of the Constitution, whereas only $5 \%$ of the Constitution has a direct positive effect on preparedness for disaster, followed by $3 \%$ prevention/mitigation, $2 \%$ reaction and recovery. If the Constitution supp orts disaster management, then the management of natural disasters becomes concrete because all the concerned authorities of the government work under pressure of the supreme law.

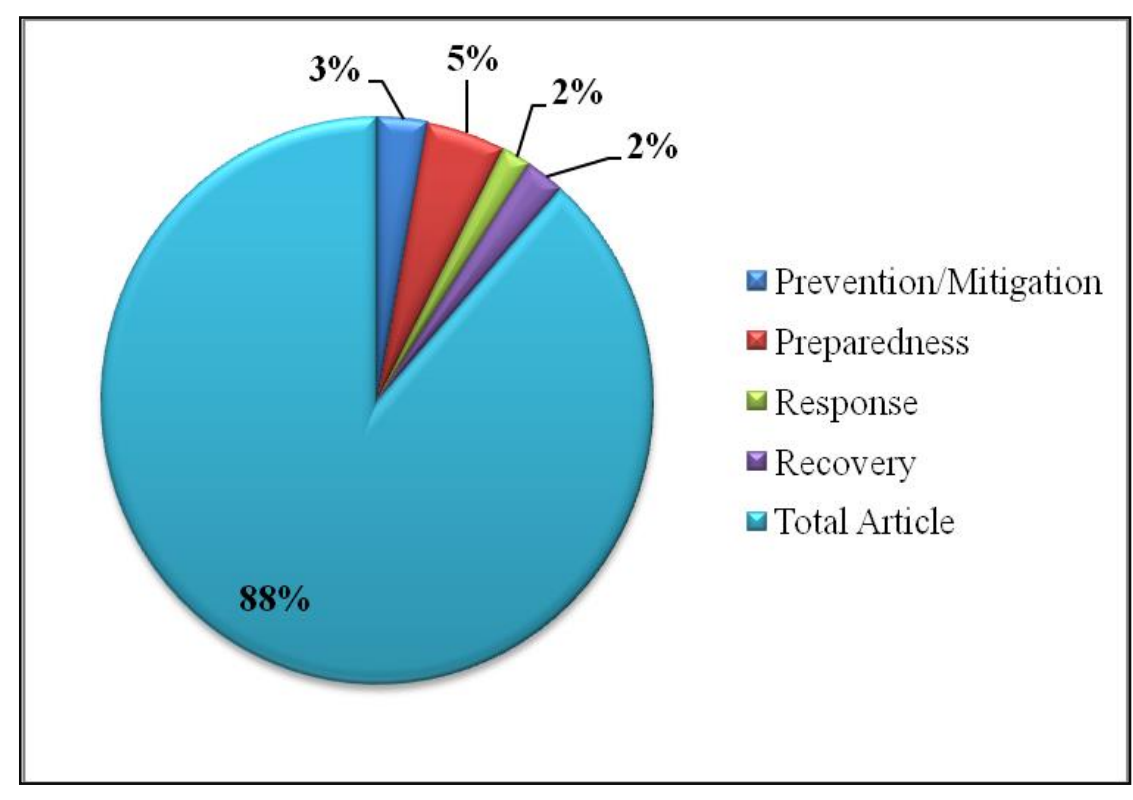

Figure 3: Positive influence of Constitution in Disaster Management cycle 
Doi: https://doi.org/10.33002/nr2581.6853.03025

\section{Conclusions}

Bangladesh Constitution was enacted in 1971. People of Bangladesh had expectations that the Constitution would ensure their rights during disasters too, as the people have the fundamental right to get basic necessities from the State. From the findings, it is observed that different articles in the Constitution of Bangladesh ensured the right of the people as far as disasters are concerned. But the people of Bangladesh are not much aware about their rights. Thus, human rights organizations can take appropriate steps to make people aware of their rights during the onset of disasters. The Government of Bangladesh has passed the Disaster Management Act in 2012, wherein the role and responsibilities of various institutions are defined at the time of disasters. But none of the articles has specifically focused on the rights of the disaster-affected people. Therefore, specially amended articles can be included focusing on the rights of disaster-affected people only. The poor, women-headed families, widows and other neglected communities should be given highest priority. The Government of Bangladesh should ensure integrated disaster risk management and adaptation strategies for most vulnerable regions of the country such as weak Chittagong hill tracts, Bhola, Hatia and other coastal districts.

\section{Acknowledgment}

The authors acknowledge the support provided by the Institute of Social Welfare \& Research and the Department of Geography \& Environment, University of Dhaka.

\section{References}

Ahamed, S., Rahman, M.M. and Faisal, M.A. (2012). Reducing cyclone Impacts in the coastal areas of Bangladesh: A case study of Kalapara Upazila. Journal of Bangladesh Institute of Planners, 5: 00-07.

Ahmed, M. (1978). Bangladesh: Constitutional Quest for Autonomy. Dhaka, Bangladesh: University Press Limited.

Alam, M., Shaifullah, A.T.M. and Mahmud, N. (2013). The Routledge International Handbook of Religious Education. London: Taylor \& Francis Group. Chapter-6, p.8.

Azad, M.A.K., Uddin, M.S., Zaman, S. and Ashraf, M.A. (2020). Community-based Disaster Management and Its Salient Features: A Policy Approach to People-centred Risk Reduction in Bangladesh. Asia-Pacific Journal of Rural Development. pp. 1-26. Doi: http://doi.org/10.1177/1018529119898036

Bankoff, G. (2002). Cultures of Disaster: Society and Natural Hazards in the Philippines. London: Routledge.

BDRCS (Bangladesh Red Cross and Red Crescent Societies) (2008). International Federation of Red Cross and Red Crescent Societies. Bangladesh. Third strategic development plan 20092010.

Berkholder-Allen, K. (1999). Media Relations and the Role of the Public Information Office: What Every DMAT Member should know. Online: http://mediccom.org/public/tadmat/training/NDMS/MediaRelationsArticle.pdf

Chaudhury, D. (1995). Constitutional development in Bangladesh. Dhaka, Bangladesh: University Press Limited.

Faisal, I.M., and Parveen, S. (2004). Food security in the face of climate change, population growth and resource constraints: implications for Bangladesh. Environ. Manage., 34: 487- 498. 
Doi: https://doi.org/10.33002/nr2581.6853.03025

Ghosh, D.K., Hossain, M.N., Sarker, M.N.S. and Islam, S. (2020). Effects of land-use changes pattern on tree plantation: Evidence from gher land in Bangladesh. International Journal of Agricultural Policy and Research, 8(3): 56-65. https://doi.org/10.15739/IJAPR.20.007

Gorum, T., Westen, C.J.V., Korup, O., Meijde, M.V.D., Fan, X. and Meer, F.D.V.D. (2013). Complex rupture mechanism and topography control symmetry of the mass-wasting pattern, 2010 Haiti earthquake. Geomorphology, 184: 127-138.

Halim, M.A. (1997). Constitution, Constitutional Law, and Politics: Bangladesh Perspective. Supreme Court of Bangladesh.

Harrison, S.E. and Johnson, P.A. (2016). Crowdsourcing the Disaster Management Cycle. International Journal of Information Systems for Crisis Response and Management, 8(4).

Hasan, M.R., Nasreen, M. and Chowdhury, M.A. (2019). Gender-inclusive disaster management policy in Bangladesh: A content analysis of national and international regulatory frameworks, International Journal of Disaster Risk Reduction, 41(2): 101324. Doi: https://doi.org/10.1016/j.ijdrr.2019.101324.

Hassan, A.A.M. (2015). Role of ICT in Natural disaster management of Bangladesh. A dissertation for the degree of Master in Disaster Management. Postgraduate programs in disaster management (PPDM), BRAC University, Dhaka, Bangladesh.

Hossain, M.F. (2011). Disaster management in Bangladesh: regulatory and social work perspectives, Journal of Comparative Social Welfare, 27(1): 91-101, Doi: http://doi.org/10.1080/17486831.2011.532978

Hossain, M.N., Rahman, M.M., Islam, K. (2016). Vulnerability of Agricultural Production due to Natural Disaster at Mongla Upazila (Sub-district) in Bangladesh. British Journal of Applied Science \& Technology, 16(1): 1-13.

Hossain, M.N., Saifullah, A.S.M., Bhuiyan, S., Uddin, N. and Rahman, M. (2019). Effects of climate change on rice production at Khulna district, Bangladesh. Environment, Earth and Ecology, 3(1): 42-54.

Hossain, M.N., Uddin, M.N., Rokanuzzaman, M., Miah, M.A. and Alauddin, M. (2015). Effects of Flooding on Socio-Economic Status of Two Integrated Char Lands of Jamuna River, Bangladesh. Journal of Environmental Science and Natural Resources, 6(2): 37-41.

Izumi, T. and Shaw, R. (2015). Disaster Management and Private Sectors: Challenges and Potentials. Japan: Springer.

Jones, S., Oven, K.J., Manyena, B. and Aryal, K. (2014). Governance struggles and policy processes in disaster risk reduction: A case study from Nepal. Geoforum, 57: 78-90. Doi: http://dx.doi.org/10.1016/j.geoforum.2014.07.011

Jonsson, U. (2003). Human Rights Approach to Development Programming. UNICEF Eastern and Southern Africa Regional Office.

Kamal, M. (1994). Bangladesh Constitution: Trends \& Issues: (2001, AD). University of Dhaka, 1994

Kent, G. (2002). The Human Right to Disaster Mitigation and Relief. Amsterdam: Elsevier Science Ltd.

Khan, M.R. and Rahman, M.A. (2007). Partnership approach to disaster management in Bangladesh: a critical policy assessment. Nat. Hazards, 41: 359-378. Doi: http://doi.org/10.1007/s11069-006-9040-y

Kingston, L.N. (2015). Protecting the world's most persecuted: the responsibility to protect and Burma's Rohingya minority. The International Journal of Human Rights, 19(8): 11631175. 
Doi: https://doi.org/10.33002/nr2581.6853.03025

Kruhl, J.H., Adhikari, R. and Dorka, U.E. (2018). Living Under the Threat of Earthquakes, Springer Natural Hazards. Cham, Switzerland: Springer International Publishing AG. https://doi.org/10.1007/978-3-319-68044-6_9

Lewis, B. and Maguire, R. (2016). A human rights-based approach to disaster displacement in the Asia-Pacific. Asian Journal of International Law, 6(2): 326-352. Doi: https://doi.org/10.1017/S2044251315000168

Mishra, D.K. (2001). Living with floods: people's perspectives. Economic and Political Weekly, 36(29): 2756-2761.

Mistri, N.A., Rahman, M. and Khatun, T. (2015). Climate Change and Food Security at Salinity Prone Area in the Southwest Coastal Region of Bangladesh. International Journal of Environmental Protection and Policy, Special Issue: Advances in Environmental Researches, 3: 35-39.

MoDMR (2010). National Plan for Disaster Management 2010-2015 (2010). Ministry of Disaster Management and Relief, Dhaka.

MoDMR (2012). National Disaster Management Act 2012. Ministry of Disaster Management and Relief, Government of the People's Republic of Bangladesh.

MoDMR (2015). National Disaster Management Policy 2015. Dhaka: Government of the People's Republic of Bangladesh.

MoEF (2013). Bangladesh Climate Change and Gender Action Plan. Ministry of Environment of Forest, Government of the People's Republic of Bangladesh, Dhaka, Bangladesh.

Momtaz, S. (2013). Human Rights Violations in Bangladesh: A Study of the Violations by the Law Enforcing Agencies. Mediterranean Journal of Social Sciences, 4(13): 1-18. Doi: http://doi.org/10.5901/mjss.2013.v4n13p101

Nasreen, M. (2009). Violence against women during flood and post-flood situations in Bangladesh. ActionAid Bangladesh. Online: http://www.actionaid.org/sites/files/actionaid/vaw_during_disasters.pdf

Pal, I. and Shaw, R. (2018). Disaster Risk Governance in India and Cross Cutting Issues: Disaster Risk Reduction. Berlin: Springer. Doi: http://doi.org/10.1007/978-981-10-3310-0_9

Panday, P.K. (2016). Politics of Land Grabbing: The Vested Property Act and the Exploitation of Hindu Communities in Bangladesh. International Journal on Minority and Group Rights, 23: 382-401. Doi: http://doi.org/10.1163/15718115-02303006

Pietropaolo, M.G. (2016). A Human Rights-Based Approach to Humanitarian Assistance. Journal of International Humanitarian Legal Studies, 7(2): 257-293. https://doi.org/10.1163/18781527-00702001

Poser, K. and Dransch, D. (2010). Volunteered Geographic Information for Disaster Management with Application to Rapid Flood Damage Estimation. Geomatica, 64: 89-98.

Potter, S.H., Becker, J.S., Johnston, D.M. and Rossiter, K.P. (2015). An overview of the impacts of the 2010-2011 Canterbury earthquakes. International Journal of Disaster Risk Reduction, 14(1): 6-14.

Rahman, A.U., Khan, A.N. and Shaw, R. (2015). Disaster Risk Reduction Approaches in Pakistan. Tokyo: Springer. Doi: http://doi.org/10.1007/978-4-431-55369-4

Rahman, R.M. (2006). Human rights, health and the state in Bangladesh. BMC International Health and Human Rights, 6: 4. Doi: http://doi.org/10.1186/1472-698X-6-4

Rezoane, Q.A. (2016). A study on Disaster Management Policy of Bangladesh: Institutional Capacity Enhancement. Master in Public Policy and Governance (MPPG) Thesis. Public Policy and Governance (PPG) Program, North South University. 
Sarker, M.N.I., Wu, M., Alam, G.M.M. and Shouse, R.C. (2019a). Administrative resilience in the face of natural disasters: Empirical evidence from Bangladesh. Polish Journal of Environmental Studies, 29(2): 1825-1837. Doi: http://doi.org/10.15244/pjoes/109527.

Sarker, M.N.I., Wu, M., Shouse, R.C. and Ma, C. (2019b). Administrative resilience and adaptive capacity of administrative system: a critical conceptual review. ICMSEM-2019. Canada: Springer. Online: https://link.springer.com/chapter/10.1007\%2F978-3-030-21255-1_55

Seekins, D. (2009). State, society and natural disaster: cyclone Nargis in Myanmar (Burma). Asian Journal of Social Science, 37(5): 717-737.

Shaw, R., Mallick, F. and Islam, A. (eds.). (2013). Disaster Risk Reduction Approaches in Bangladesh. Tokyo: Springer. Online: https://doi.org/10.1007/978-4-431-54252-0

Siddiqui, K.U., and Hossain, A.N.H.A. (2006). The Impact of Floods on Bangladesh and Options for Mitigation: An Overview, In Options for Flood Risk and Damage Reduction in Bangladesh. Dhaka, Bangladesh: University Press Limited.

South, A. (2008). Ethnic Politics in Burma: States of conflict. London and New York: Routledge Taylor \& Francis Group.

Suwanvanichkij, V., Murakami, N., Lee, C., Leigh, J., Wirtz, A.L., Daniels, B., Mahn, M., Maung, C. and Beyrer, C. (2010). Community-based assessment of human rights in a complex humanitarian emergency: The Emergency Assistance Teams-Burma and Cyclone Nargis. Conflict and Health, 4(8): 1-14. Online: http://www.conflictandhealth.com/content/4/1/8

UNISDR (United Nations International Strategy for Disaster Reduction), (2015). UNISDR terminology on disaster risk management. Geneva, Switzerland. Accessed on 2 July 2012. Available online: https://www.unisdr.org

UNISDR. (2005). Hyogo Framework for Action 2005-2015: Building the Resilience of Nations and Communities to Disasters. United Nations International Strategy for Disaster Reduction.

Warfield, C. (2005). The disaster management cycle. "Global Development Research Centre". Online: http://www.gdrc.org/uem/disasters/1-dm_cycle.html (accessed 17 July 2012). 